\title{
GCU
}

Glasgow Caledonian

University

University for the Common Good

\section{Removal of sulfadiazine by ferrate(VI) oxidation and montmorillonite adsorption - synergistic effect and degradation pathways}

Wang, Hongyu ; Wang, Shujuan; Jiang, Jia-Qian; Shu, Ji

Published in:

Journal of Environmental Chemical Engineering

DOI:

10.1016/j.jece.2019.103225

Publication date:

2019

Document Version

Author accepted manuscript

Link to publication in ResearchOnline

Citation for published version (Harvard):

Wang, H, Wang, S, Jiang, J-Q \& Shu, J 2019, 'Removal of sulfadiazine by ferrate(VI) oxidation and

montmorillonite adsorption - synergistic effect and degradation pathways', Journal of Environmental Chemical Engineering, vol. 7, no. 4, 103225. https://doi.org/10.1016/j.jece.2019.103225

\section{General rights}

Copyright and moral rights for the publications made accessible in the public portal are retained by the authors and/or other copyright owners and it is a condition of accessing publications that users recognise and abide by the legal requirements associated with these rights.

Take down policy

If you believe that this document breaches copyright please view our takedown policy at https://edshare.gcu.ac.uk/id/eprint/5179 for details

of how to contact us. 


\section{Accepted Manuscript}

Title: Removal of sulfadiazine by ferrate(VI) oxidation and montmorillonite adsorption - synergistic effect and degradation pathways

Authors: Hongyu Wang, Shujuan Wang, Jia-Qian Jiang, Ji Shu

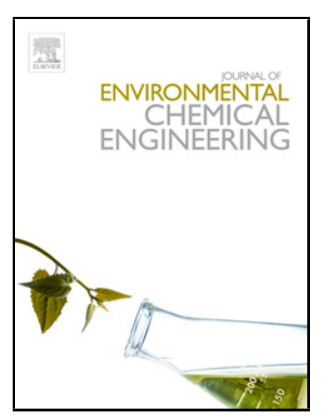

PII: $\quad$ S2213-3437(19)30348-3

DOI: $\quad$ https://doi.org/10.1016/j.jece.2019.103225

Article Number: $\quad 103225$

Reference: $\quad$ JECE 103225

To appear in:

Received date: $\quad 6$ April 2019

Revised date: $\quad 18$ June 2019

Accepted date: $\quad 21$ June 2019

Please cite this article as: Wang H, Wang S, Jiang J-Qian, Shu J, Removal of sulfadiazine by ferrate(VI) oxidation and montmorillonite adsorption - synergistic effect and degradation pathways, Journal of Environmental Chemical Engineering (2019), https://doi.org/10.1016/j.jece.2019.103225

This is a PDF file of an unedited manuscript that has been accepted for publication. As a service to our customers we are providing this early version of the manuscript. The manuscript will undergo copyediting, typesetting, and review of the resulting proof before it is published in its final form. Please note that during the production process errors may be discovered which could affect the content, and all legal disclaimers that apply to the journal pertain. 
Removal of sulfadiazine by ferrate(VI) oxidation and montmorillonite adsorption - synergistic effect and degradation pathways

Hongyu Wang ${ }^{\mathrm{a} *}$, Shujuan Wang ${ }^{\mathrm{b}}$, Jia-Qian Jiang ${ }^{\mathrm{c} *}, \mathrm{Ji}^{\mathrm{Sh}} \mathrm{Sh}^{\mathrm{b}}$

${ }^{a}$ School of Environment, Zhejiang University of Technology, Hangzhou, 310014, China

${ }^{b}$ School of Civil Engineering and Architecture, Zhejiang University of Technology, Hangzhou, 310023, China

${ }^{c}$ SCEBE, Department of Civil Engineering and Environmental Management, Glasgow Caledonian University, Glasgow G4 OBA, Scotland, U.K.

*Corresponding authors: jiaqian.jiang@gcu.ac.uk; hywang@zjut.edu.cn

\section{Highlights}

- First reporting the removal of sulfadiazine by ferrate(VI) oxidation and montmorillonite adsorption

- Positive synergetic effect of a combined oxidation/adsorption process on the SDZ treatment was confirmed

- Degradation of SDZ by ferrate(VI) fitted in pseudo-order equation and the kinetic rate constant was derived

- Pathways of sulfadiazine's degradation by ferrate(VI) and potential oxidation product formation were explored

\footnotetext{
ABSTRACT

Antibiotics have been frequently detected in the environment and watercourses which can inspire bacterial resistance and create super-bacteria; resulting in potential adverse impacts on the human health and environment. This work thus investigated the synergistic effect of a combined process (ferrate(VI) oxidation with montmorillonite adsorption), in comparison with either the oxidation or adsorption alone, for the removal of one of
} 
antibiotics, sulfadiazine (SDZ). The results manifested that all the three combined processes can promote the removal of SDZ but the simultaneous oxidation and adsorption can achieve the outperforming removal of SDZ (76.20\%) in comparison with the oxidation alone $(60 \%)$ or adsorption alone $(10 \%)$ for the same given conditions, and the synergistic effect of combined oxidation/adsorption was confirmed. Additionally, the degradation of SDZ by ferrate(VI) fitted in the pseudo-second-order reaction characteristics, and the total reaction rate constant was derived as $2.97 * 10^{-4} \mathrm{~L}^{2} \cdot \mathrm{mg}^{-2} \cdot \mathrm{min}^{-1}$. The study also explored the possible pathways of the SDZ degradation by ferrate(VI) and potential oxidation product formation when an incompletemineralization of SDZ was observed. The oxidation product formed was proposed as a macromolecular-like compound containing $\mathrm{R}-\mathrm{NO}_{2}$ groups which were oxidized from the initial structure of $\mathrm{SDZ}$ containing $\mathrm{R}-\mathrm{NH}_{2}$ groups.

Keywords:

Ferrate(VI); Degradation and its pathways; Montmorillonite; Oxidation; Sorption; Sulfadiazine (SDZ)

\section{Introduction}

The pharmaceutical and personal care products (PPCPs) are emerging pollutants and have attracted attention world widely [1]. As one type of these emerging contaminants, antibiotics have received much attention because there are tremendous use of antibiotics in human and veterinary medicine as well as in agriculture and aquaculture activities [2]. The ever-increasing use of antibiotics in human medicine and animal husbandry resulted in their "pseudo-durability" [3-4] and residual antibiotics in the environment have been constantly detected [5-9]. It is challenging to remove these pollutants from water and wastewater by the traditional water treatment processes due to their durability and difficult degradability [10]. The undesirable existence of antibiotics can raise the possible formation of antibiotic resistant genes and lead to the alteration of microbial community composition [11]. Consequently, this will pose a great threat to human health and ecosystem. Many antibiotics have been frequently detected in surface water [12], groundwater [13], soils [14] and sediments [15]. What is more, the concentration of these antibiotics in water courses gradually increased from $n g \mathrm{~L}^{-1}$ to $\mu \mathrm{g} \mathrm{L}^{-1}$ levels [16]. Sulfadiazine (SDZ) has been used as one of antibiotics and has a broader activity to inhibit bacterial pathogens (e.g., Gram (-) and Gram (+) bacteria). Because of this, SDZ has been widely applied in curing diseases causing from bacterial infections [17], and its residuals in watercourses have been detected world widely; e.g., $71.8 \mathrm{ng} \mathrm{L}^{-1}$ in the Yangtze Estuary 
[18], $157 \mathrm{ng} \mathrm{L}^{-1}$ in the Beiyun River of Beijing [19], $147 \mathrm{ng} \mathrm{L}^{-1}$ in the Soeste River of Germany [20] and $94.2 \mathrm{ng} \mathrm{L}^{-1}$ in the Langat River basin in Malaysia [21].

The toxicity of SDZ to various organisms has been identified as well, including Caenorhabditis elegans [22], Sparus aurata [23] and Daphnia magna [24]. One of other studies reported that SDZ could inhibit the nitrification process in an activated sludge system [25]. Accordingly, SDZ poses a potential hazard to humans, mainly through the food chain and drinking water [26]. Due to this, researches [27] have been carried out to study the effect of SDZ on the environment and public health, as exceedingly detailed.

In the past few decades, researches using chemical oxidation techniques, such as ferrate(VI), persulfate, Fenton reagent and ozonation, were carried out to remove the selected antibiotics' residuals in aqueous phase [28-31]. Among these technologies, ferrate(VI) has received extensive attentions due to its superior dual properties of oxidation and coagulation. Ferrate(VI) is a green and environmentally friendly oxidant, with a redox potential varying from $+2.2 \mathrm{~V}$ to $+0.7 \mathrm{~V}$ in acidic and basic solutions, respectively [32-33]. Ferrate(VI) can perform oxidation, coagulation, adsorption, sedimentation, disinfection, decolorization and deodorization, and these functions are unmatched by other water treatment reagents. And therefore, over the years, there have been numerous studies on ferrate(VI) in the treatment of a wide range of contaminants due to its typical characteristics [34-37]. Such as accelerate and promote the removal of contaminants by Ferrate(VI) by adding single-electron and two-electrons' transfer reducing agents [38]; Removal of quinolone antibiotics by ammoxidation of Ferrate(VI) [39]. And the use of Ferrate(VI)-sulfur(IV) system to enhance the anti-oxidation effect of antibiotics [40].

Adsorption has played an important role in the removal of pollutants in water treatment. The most significant factors on adsorption between adsorbents and adsorbates are hydrophobic and electrostatic interactions [41]. Many clay minerals such as montmorillonite have large specific surface area (SSA) and high cation exchange capacity (CEC) [42]. As a natural silicate mineral, montmorillonite is known as "universal material" and has strong sorption capacity, especially when it has been modified per given conditions. Consequently, the sorption researches using modified montmorillonites have been widely carried out [43].

In terms of specific characterizations of both ferrate(VI) and montmorillonite as detailed above and due to using ferrate(VI) alone can't completely oxidize many organic pollutants, a combination process involving ferrate(VI) oxidation and montmorillonite adsorption could be tested to compensate the drawbacks of ferrate(VI) process and to enhance the overall removal efficiency by introducing an additional adsorption process. 
And then, the aims of this study were to investigate the performance of ferrate(VI) oxidation and montmorillonite sorption for the removal of sulfadiazine (SDZ). The study paid attention to the synergetic effect of the combined oxidation/sorption process on the efficiency of the SDZ treatment. Moreover, the research was aiming at investigating the possible oxidation product formation, proposing degradation pathways and deriving SDZ's degradation kinetic rate constant.

\section{Materials and methods}

\subsection{Reagents and solutions}

SDZ was purchased from Sigma Aldrich (Shanghai, China). Other chemicals used in the experiments were of analytical grade and were purchased from Hangzhou Xiaoshan Chemical Reagent Factory (Hangzhou, China). Ferrate(VI) $\left(\mathrm{K}_{2} \mathrm{FeO}_{4}\right)$ of $98 \%$ purity was purchased from Sigma-Aldrich, and its purity was checked by the titration method using $\mathrm{Fe}\left(\mathrm{NH}_{4}\right)_{2}\left(\mathrm{SO}_{4}\right)_{2}$, which was calibrated by the titration of $\mathrm{K}_{2} \mathrm{Cr}_{2} \mathrm{O}_{7}$ before the experiment [32].

All chemical solutions were prepared with ultrapure water (UPHW1-90 T, Sichuan Europtronic Ultrapure Technology Co. Ltd., China). The solution of SDZ (0.02 mM) was prepared for the use of oxidation experiments and montmorillonite adsorption. The working solution of ferrate(VI) was prepared on site and was prepared before experiments by adding solid $\mathrm{K}_{2} \mathrm{FeO}_{4}$ to $\mathrm{pH}$ buffer $\left(5 \mathrm{mM} \mathrm{Na}_{2} \mathrm{HPO}_{4}\right.$ and $\mathrm{Na}_{2} \mathrm{~B}_{4} \mathrm{O}_{7} \cdot 9 \mathrm{H}_{2} \mathrm{O}$, pH = 9.2) and used within $10 \mathrm{~min}$. The $\mathrm{pH}$ of the ferrate(VI) solutions was $\approx 9.2$. Both potassium dihydrogen phosphate and methanol are chromatographic grade.

\subsection{Experiment method}

\subsubsection{Degradation experiments}

The oxidation of SDZ by ferrate(VI) was performed in a $500 \mathrm{~mL}$ flask, which was filled in $400 \mathrm{~mL} \mathrm{SDZ} \mathrm{solution}(0.02 \mathrm{mM})$, and the flask was placed on a magnetic stirrer (IKA, Schwarzwald, Germany) with a fixed speed of $600 \mathrm{rpm} \mathrm{min}{ }^{-1}$. Either hydrochloric acid $(0.1 \mathrm{M})$ or sodium hydroxide $(0.1 \mathrm{M})$ solution was used to adjust the given $\mathrm{pH}$ value of SDZ solution. After the addition of ferrate(VI) ([Fe(VI):[SDZ] $=10: 1), 20 \mathrm{~mL}$ of ferrate(VI)/SDZ mixed solution was pipetted out from the reaction system at designed time intervals up to $60 \mathrm{~min}$. And then, $0.5 \mathrm{~mL}$ of sodium thiosulfate $(0.1 \mathrm{M})$ was added into the mixture to quench the oxidation, and portion of the sample was filtered through a $0.22 \mu \mathrm{m}$ membrane filter for measuring the remaining SDZ concentrations (by the liquid chromatography procedures which can be seen in section 2.2.4) and another portion of the 
sample was filtered through a $0.45 \mu \mathrm{m}$ membrane filter for measuring the remaining dissolved organic carbon (DOC).

\subsubsection{Adsorption experiments}

$50 \mathrm{~mL}$ SDZ solution $(0.02 \mathrm{mM})$ was filled in a $100 \mathrm{~mL}$ flask. Montmorillonite was dosed into the flask for a given weight ratio, 20:1 (montmorillonite:SDZ). The sorption $\mathrm{pH}$ was adjusted by either hydrochloric acid $(0.1 \mathrm{M})$ or sodium hydroxide $(0.1 \mathrm{M})$ solution to that of 4-10. The mixture solution of montmorillonite and SDZ was placed in a thermostatic oscillator (IKA, Schwarzwald, Germany), and stirred at a speed of $200 \mathrm{rpm}$ $\min ^{-1}\left(25^{\circ} \mathrm{C}\right)$. After 24 hours of reaction, the mixture was centrifuged (H-1650, Changsha Xiangzhi centrifuge instrument Co. Ltd., China) for $10 \mathrm{~min}\left(10000 \mathrm{rpm} \mathrm{min}{ }^{-1}\right)$, and the supernatant was filtered through a $0.22 \mu \mathrm{m}$ membrane. The residual concentrations of SDZ were analyzed using the procedures as detailed in 2.2.4.

\subsubsection{Combined process of oxidation and adsorption}

The combined oxidation and sorption experiments were divided into three parts to demonstrate the effect of the order of oxidation and adsorption on the removal of SDZ.

a) SDZ was oxidized first (by ferrate(VI)) and then adsorbed (by montmorillonite). The oxidation phase was performed in a $100 \mathrm{~mL}$ flask which containing $50 \mathrm{~mL}$ SDZ solution $(0.02 \mathrm{mM})$. After dosing ferrate(VI) at the molar ratio 10:1 (Fe(VI):SDZ), the flask was placed on a magnetic stirrer (IKA, Schwarzwald, Germany), mixed with a fixed speed of $200 \mathrm{rpm} \mathrm{min}^{-1}$. After $1 \mathrm{~h}$ mixing, $1 \mathrm{~mL}$ of solution was pipetted out from the flask, $30 \mu \mathrm{L}$ of sodium thiosulfate was added into it as a quencher, and then it was filtered through a $0.22 \mu \mathrm{m}$ membrane filter for measuring the residual concentrations of SDZ after ferrate(VI) oxidation. Following that, $5 \mathrm{mg}$ montmorillonite was added into the pre-oxidized solution and the mixture was mixed for $24 \mathrm{~h}$ with a shaking speed of $200 \mathrm{rpm}\left(25^{\circ} \mathrm{C}\right)$. After that, the mixture was separated by centrifugation for $10 \mathrm{~min}(10000 \mathrm{rpm})$, the resulting supernatant was then filtered through a $0.22 \mu \mathrm{m}$ membrane and used to detect the concentrations of SDZ.

b) Performed the adsorption first (by montmorillonite, $24 \mathrm{~h}$ ) and then the oxidation (with ferrate(VI) for $1 \mathrm{~h}$ ) afterwards. The volume of samples, SDZ concentration, and the procedures of the adsorption and oxidation were the same as (a).

c) Simultaneous oxidation and adsorption. The $50 \mathrm{~mL} 0.02 \mathrm{mM} \mathrm{SDZ} \mathrm{solution} \mathrm{(about}$ $0.001 \mathrm{mM}$ ) was placed in a $100 \mathrm{~mL}$ flask, which was placed on a magnetic stirrer. Ferrate(VI) with the molar ratio of 10:1 (Fe(VI):SDZ) and 5mg montmorillonite were added into the flask simultaneously, and the mixture was blended with a fixed speed of $200 \mathrm{rpm}$ for $1 \mathrm{~h}$ and $24 \mathrm{~h}$ respectively. The mixture was then centrifuged for $10 \mathrm{~min}$ 
(10000 rpm), and the supernatant was filtered through a $0.22 \mu \mathrm{m}$ membrane and was ready for the measurement of concentrations of SDZ.

\subsubsection{Analytical methods}

The concentrations of SDZ were determined by a Shimadzu LC-20A system (Shimadzu, Japan) equipped with a quaternary pump and an ultraviolet detector (SPD-20A, Shimadzu, Japan). Chromatographic analysis was carried out at a flow rate of $0.9 \mathrm{~mL} \mathrm{~min}^{-1}$ on an Inertsil ODS-3 C18 analytical column ( $4.6 \mathrm{~mm} * 250 \mathrm{~mm}$, particle size $5 \mu \mathrm{m})$ (Shimadzu, Japan) at $40^{\circ} \mathrm{C}$. The mobile phase was $70 \%$ potassium dihydrogen phosphate $(0.02 \mathrm{M}, \mathrm{pH}$ $=3.5)(\mathrm{A})$ and $30 \%$ methanol (B). The injection volume was $20 \mu \mathrm{L}$ and the UV detection wavelength was $265 \mathrm{~nm}$. Elution time was $8 \mathrm{~min}$ for all samples.

For the identification of degradation intermediates, samples were analyzed by GC-MS (Saturn, USA) equipped with an SE-54 capillary column (Chromse, UK). All samples were prepared to $\mathrm{pH}<1$ with $1 \mathrm{~mol} \mathrm{~L}^{-1} \mathrm{HCl}$, and then extracted with chloroform (10 times concentrated) with recovery rate of $76 \%$. The GC-MS conditions were given as follows: 1 $\mu \mathrm{L}$ sample was injected without pyrolysis at $280^{\circ} \mathrm{C}$ and the column temperature was programmed from $50^{\circ} \mathrm{C}(5 \mathrm{~min})$ to $250{ }^{\circ} \mathrm{C}$ at $10^{\circ} \mathrm{C} \mathrm{min}^{-1}$ followed by a $5 \mathrm{~min}$ hold at $250^{\circ} \mathrm{C}$. Helium (> 99.999\%) was used as carrier gas and the flow rate was $0.8 \mathrm{~mL} \mathrm{~min}^{-1}$. The mass spectrometer operates under the electron ionization mode of $70 \mathrm{eV}$ and the mass scanning range is $40-500$.

Dissolved organic carbon (DOC) concertation in the solution before and after treatment was measured by the established procedures using Shimadzu TOC-L Analyzer (Japan). Zeta potential was measured following a standard procedure using a nanometer particle size analyzer (NanoZS90, Malvern, England), where $4 \mathrm{~mL}$ of the mixed solution after the reaction was placed in a $4 \mathrm{~mL}$ centrifuge tube for 5 minutes centrifuged $(\mathrm{H}-1650$, Changsha Xiangzhi centrifuge instrument Co. Ltd., China), then the supernatant was taken in a sample spoon for the Zeta potential reading.

\section{Results and discussion}

\subsection{Degradation of SDZ}

\subsubsection{Effect of ferrate(VI) dosage}

In this study, relative high concentration of SDZ was used in order to study kinetics and oxidation pathways and by-products formation. It could be suggested that the ferrate performance of treating SDZ in real wastewater will be affected by many other factors especially the presence of many other organic contaminants. And then the performance 
might be different from that was observed in this study. The removal efficiency of SDZ by ferrate(VI) at $\mathrm{pH} 7.0$ and different ferrate(VI) doses (as $\mathrm{Fe}(\mathrm{VI})$ :SDZ molar ratios from 10:1 to 50:1) was shown in Fig. 1. When the molar ratio was 10:1 (Fe(VI):SDZ) and reaction time of $15 \mathrm{~min}$, the removal efficiency of SDZ can reach $60.40 \%$ (Fig. 1). And with the increasing in dosage of ferrate(VI), the removal efficiency of SDZ was gradually increased; e.g., dose of 50:1 (Fe(VI):SDZ, molar ratio) can achieve 99.9\% degradation of SDZ in comparison with that about $74 \%$ for the dose of $20: 1$ and reaction time of $60 \mathrm{~min}$. (Fig. 1). Fig. 1 also shows that for the ferrate(VI) dose of less than 40:1, increasing reaction time over $30 \mathrm{~min}$ was not beneficial to the high removal efficiency achieved.

Fig. 1. Effect of ferrate(VI) dose (as molar ratios of $\mathrm{Fe}(\mathrm{VI})$ :SDZ) and reaction time on the removal of SDZ $\left([\mathrm{SDZ}]_{0}=0.02 \mathrm{mM} ; \mathrm{pH}=7.0 \pm 0.1 ; \mathrm{T}=25.0{ }^{\circ} \mathrm{C}\right)$

\subsubsection{Effect of solution $\mathrm{pH}$}

Fig. 2 shows the variation of SDZ degradation by ferrate(VI) at different $\mathrm{pH}$ values and reaction time. For all $\mathrm{pH}$ studied, increasing reaction time promoted to the high removal efficiency of SDZ by ferrate(VI) and the oxidation reactions reached the equilibrium in about 15 minutes. The maximum removal percentage of SDZ was achieved at $\mathrm{pH} 7(60 \%)$ and with the increase of $\mathrm{pH}$ greater than 7 , the SDZ removal decreased.

In the process of oxidation, $\mathrm{pH}$ was always regarded as one of key factors influencing the degradation of organic contaminants. According to Rush et al. [44], ferrate(VI) can be dissociated into various species under different $\mathrm{pH}$ conditions and the oxidizing ability and stability of different ferrate(VI) species are variable. Ferrate(VI) may exist in different forms, namely $\mathrm{H}_{3} \mathrm{FeO}_{4}{ }^{+}, \mathrm{H}_{2} \mathrm{FeO}_{4}, \mathrm{HFeO}_{4}{ }^{-}$and $\mathrm{FeO}_{4}{ }^{2-}$, so the $\mathrm{pH}$ of the solution system has an great impact on oxidative property and stability to Ferrate (VI). The major forms of ferrate(VI) in solution are $\mathrm{H}_{3} \mathrm{FeO}_{4}{ }^{+}$and $\mathrm{H}_{2} \mathrm{FeO}_{4}$ when $\mathrm{pH}$ of the solution is 3 or less (Eq. 1); $\mathrm{H}_{2} \mathrm{FeO}_{4}$ and $\mathrm{HFeO}_{4}{ }^{-}$when $\mathrm{pH}$ ranges 3.5 to 7.3 (Eq. 2), and they are all present in the form of $\mathrm{FeO}_{4}{ }^{2-}$ when $\mathrm{pH}$ of the solution is higher than 7.3 (Eq. 3). Studies have demonstrated that $\mathrm{HFeO}_{4}{ }^{-}$was the most active substance in many reactions [45]. $\mathrm{HFeO}_{4}{ }^{-}$ has a larger spin density on the oxo-ligands than $\mathrm{FeO}_{4}{ }^{2-}$ in line with the density functional theory, which increases the oxidation ability of protonated ferrate(VI) [46]. And this is consistent with the superior removal $(60 \%)$ of SDZ observed at pH 7 and decreasing in the removal efficiency when $\mathrm{pH}$ was $>7$ (Fig. 2). 


$$
\begin{aligned}
& \mathrm{H}_{3} \mathrm{FeO}_{4}{ }^{+} \rightarrow \mathrm{H}^{+}+\mathrm{H}_{2} \mathrm{FeO}_{4}, p K_{a}=1.6+0.2 \\
& \mathrm{H}_{2} \mathrm{FeO}_{4} \rightarrow \mathrm{H}^{+}+\mathrm{HFeO}_{4}{ }^{-}, p K_{a}=3.5 \\
& \mathrm{HFeO}_{4}{ }^{-} \rightarrow \mathrm{H}^{+}+\mathrm{FeO}_{4}{ }^{2-}, p K_{a}=7.3+0.1
\end{aligned}
$$

Fig. 2. Effect of different $\mathrm{pH}$ values on $\mathrm{SDZ}$ degradation ([Fe(VI)]:[SDZ] = 10:1; $[\mathrm{SDZ}]=$ $\left.0.02 \mathrm{mM} ; \mathrm{pH}=5.0-10.0 ; \mathrm{T}=25.0^{\circ} \mathrm{C}\right)$.

\subsubsection{Reaction kinetics}

It is acknowledged that the concentration of oxidant can dominant the removal efficiency of micro-pollutants in the oxidation process. As shown in Fig.1, the removal rate of SDZ was positively relevant to the dosage of ferrate(VI). The oxidation kinetics of SDZ by ferrate (VI) was fitted in pseudo-order equation as shown below:

$\mathrm{r}=-\frac{\mathrm{d}[\mathrm{SDZ}]_{t}}{d_{t}}=k \cdot[\text { Ferrate }(V I)]^{a} \cdot[S D Z]^{b}$

Where $\mathrm{r}$ represents the reaction rate of SDZ, $\mathrm{k}$ represents the overall rate constant of SDZ by Ferrate(VI), $a$ and $b$ represent the orders of the reaction, [Ferrate(VI)] and [SDZ] represent the concentrations of ferrate(VI) and SDZ. Let

$k_{1}=k \cdot[\operatorname{Ferrate}(V I)]^{a}$

Eq. (4) can be rewritten as

$\mathrm{r}=k_{1} \cdot[S D Z]^{b}$

Take the natural logarithm on both sides of Eq. (5) and Eq. (6)

$\ln k_{1}=\ln k+a * \ln [\operatorname{Ferrate}(V I)]$

$\ln r=\ln k_{1}+b * \ln [S D Z]$

Table 1 shows the different ferrate(VI) dosages, initial concentrations of SDZ, the fitting equations, and the initial reaction rate of SDZ. According to the fitting equations, it is linear with good correlation $\left(\mathrm{R}^{2}>0.90\right)$ between SDZ concentrations in the reaction process and the reaction time, indicating that the oxidation of SDZ by ferrate(VI) was a first-order 
reaction. Fig. 3 shows that the values of $a$ and $b$ are 0.71 and 0.89 , respectively. Finally, the interception value on the vertical axis shows that the value of the reaction rate constant $\mathrm{r}$ was $2.97 * 10^{-4} \mathrm{~L}^{2} \cdot \mathrm{mg}^{-2} \cdot \mathrm{min}^{-1}$. So the rate expression for the reaction of ferrate(VI) with SDZ can be expressed as

$$
\mathrm{r}=-\frac{\mathrm{d}[\mathrm{SDZ}]_{\mathrm{t}}}{\mathrm{d}_{\mathrm{t}}}=2.97 \times 10^{-4} \cdot[\text { Ferrate }(\mathrm{VI})]^{0.71} \cdot[\mathrm{SDZ}]^{0.89}
$$

In this study, kinetic experiments were performed at $\mathrm{pH}$, where ferrate(VI) presented in the solution would be of majority as $\mathrm{FeO}_{4}{ }^{2-}$ (Eq. 3); and thus the derived rate constant as shown above is only a representative for the given ferrate(VI) species in the oxidation of SDZ. However, for a comprehensive estimation of the rate constant for ferrate(VI) with SDZ, a wide $\mathrm{pH}$ range, say, 5-11, could be considered. Since under such a $\mathrm{pH}$ range, all ferrate(VI) species (Eqs. 1-3) will be included and kinetics of their reaction with selected micro pollutants will be estimated individually and this could give out an overall secondorder reaction rate constant. Examples of such efforts can be seen in references [47-48].

Fig. 3. Kinetics analysis of SDZ degradation by ferrate(VI)

\section{Table 1}

Kinetic parameters of SDZ degradation by ferrate(VI)

\begin{tabular}{llllll}
\hline $\begin{array}{l}\text { D Ferrate(VI) } \\
\left(\mathrm{mg} \mathrm{L}^{-1}\right)\end{array}$ & $\begin{array}{l}\mathrm{C}_{\mathrm{ISDZ}} \\
\left(\mu \mathrm{g} \mathrm{L}^{-1}\right)\end{array}$ & Fitting equation & $\begin{array}{l}\mathrm{K}_{\mathrm{obs}} \\
\left(\mathrm{min}^{-1}\right)\end{array}$ & $\mathrm{R}^{2}$ & $\begin{array}{l}\mathrm{R}_{\mathrm{IR}} \\
\left(\mathrm{ug} \mathrm{L}^{-1} \mathrm{~min}^{-1}\right)\end{array}$ \\
\hline 39.6 & 5000 & $1 / \mathrm{C}=0.0004 \mathrm{X}+0.1961$ & 0.0004 & 0.9466 & 207.9 \\
79.2 & 5000 & $1 / \mathrm{C}=0.0067 \mathrm{X}+0.188$ & 0.0067 & 0.9275 & 341.1 \\
118.8 & 5000 & $1 / \mathrm{C}=0.0083 \mathrm{X}+0.1839$ & 0.0083 & 0.9182 & 522.6 \\
158.4 & 5000 & $1 / \mathrm{C}=0.011 \mathrm{X}+0.178$ & 0.011 & 0.9202 & 639.3 \\
158.4 & 1000 & $\operatorname{lnC}=-0.0981 \mathrm{X}+0.384$ & 0.0981 & 0.9837 & 638.2 \\
158.4 & 2000 & $\operatorname{lnC}=-0.0849 \mathrm{X}+0.349$ & 0.0849 & 0.9584 & 397.2 \\
158.4 & 3000 & $\operatorname{lnC}=-0.08 \mathrm{X}+0.759$ & 0.08 & 0.9512 & 271.2 \\
158.4 & 4000 & $\operatorname{lnC}=-0.0743 \mathrm{X}+1.033$ & 0.0743 & 0.9377 & 178.4 \\
\hline
\end{tabular}

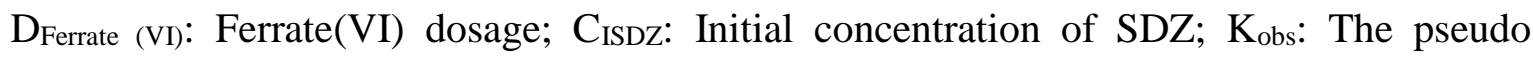


reaction rate constant; $\mathrm{R}_{\mathrm{IR}}$ : Initial reaction rate.

\subsection{Adsorption experiment}

\subsubsection{Adsorption isotherms}

The adsorption isotherm of SDZ onto montmorillonite was determined by plotting the amount of SDZ adsorbed by montmorillonite $\left(\mathrm{Q}_{\mathrm{e}}, \mathrm{mg}^{-1}\right)$ versus the equilibrium concentration of SDZ $\left(\mathrm{C}_{\mathrm{e}}, \mathrm{mg} \mathrm{\textrm {L } ^ { - 1 }}\right)$. The adsorption isotherms of SDZ from aqueous solution onto KSF at different temperatures with initial $\mathrm{pH} 7$ were shown in Fig. 4. Two adsorption models (Langmuir and Freundlich) were used to describe the equilibrium between adsorbed SDZ onto montmorillonite $\left(\mathrm{Q}_{\mathrm{e}}\right)$ and $\mathrm{SDZ}$ in solution $\left(\mathrm{C}_{\mathrm{e}}\right)$ at constant temperatures.

Fig. 4. Adsorption isotherms of SDZ on montmorillonite at different temperatures $\left([\right.$ montmorillonite $]=1000 \mathrm{mg} \mathrm{L}^{-1} ; \mathrm{pH}=7.0 \pm 0.1 ;$ sorption time $\left.=24 \mathrm{~h}\right)$

\section{a. Langmuir isotherm}

The Langmuir isotherm theory assumes that the adsorbate is monolayer coverage on the surface of a homogeneous adsorbent [49]. Linear form of Langmuir equation was applied to obtain sorption capacity of SDZ on montmorillonite:

$$
\frac{C_{e}}{Q_{e}}=\frac{1}{L Q_{m}}+\frac{C_{e}}{Q_{m}}
$$

Where $\mathrm{C}_{\mathrm{e}}$ represents the equilibrium concentration of SDZ $\left(\mathrm{mg} \mathrm{L}^{-1}\right), \mathrm{Q}_{\mathrm{e}}$ represents the amount of SDZ adsorbed by montmorillonite $\left(\mathrm{mg} \mathrm{g}^{-1}\right), \mathrm{Q}_{\mathrm{m}}$ represents the maximum adsorption capacity of SDZ onto montmorillonite $\left(\mathrm{mg} \mathrm{g}^{-1}\right)$, $\mathrm{L}$ is the Langmuir constant. The sorption parameters of SDZ adsorption onto montmorillonite corresponding to Langmuir equation were summarized in Table 2.

\section{Table 2}

The sorption parameters of Langmuir equation for SDZ onto montmorillonite at different temperatures

\begin{tabular}{cccl}
\hline Temperature $\left({ }^{\circ} \mathrm{C}\right)$ & $\mathrm{R}^{2}$ & $\mathrm{Qm}_{\mathrm{m}\left(\mathrm{mg} \mathrm{g}^{-1}\right)}$ & $\mathrm{L}\left(\mathrm{L} \mathrm{mg}^{-1}\right)$ \\
\hline 25 & 0.9982 & 31.57 & 2.7602 \\
& & & \\
\hline
\end{tabular}




\begin{tabular}{llll}
\hline 35 & 0.9995 & 42.37 & 4.3312 \\
45 & 0.9959 & 23.92 & 8.8540 \\
\hline
\end{tabular}

$\mathrm{Q}_{\mathrm{m}}$ : the maximum adsorption capacity of SDZ onto montmorillonite $\left(\mathrm{mgg}^{-1}\right)$; L: Langmuir constant.

\section{b. Freundlich isotherm}

Freundlich isotherm assumes that as the adsorbate concentration increases so too does the concentration of adsorbate on the adsorbent surface. And the Freundlich isotherm equation was as follows [50]:

$Q_{e}=K \cdot C_{e}^{\frac{1}{n}}$

Where $C_{e}$ represents the equilibrium concentration of SDZ $\left(\mathrm{mg} \mathrm{L}^{-1}\right), \mathrm{Q}_{\mathrm{e}}$ represents the amount of SDZ adsorbed by montmorillonite $\left(\mathrm{mgg}^{-1}\right), \mathrm{K}$ and $\mathrm{n}$ are the indicators of adsorption capacity and heterogeneity factor, respectively [51]. Take the natural logarithm on both sides of Eq. (10)

$\ln Q_{e}=\ln K+\frac{1}{n} * \ln C_{e}$

The sorption parameters of SDZ adsorption onto montmorillonite corresponding to Langmuir equation were summarized in Table 3.

\section{Table 3}

The sorption parameters of Fruendlich equation for SDZ onto montmorillonite at different temperatures.

\begin{tabular}{cccc}
\hline Temperature $\left({ }^{\circ} \mathrm{C}\right)$ & $\mathrm{R}^{2}$ & $\mathrm{~K}$ & $\mathrm{n}$ \\
\hline 25 & 0.9217 & 0.396 & 1.083 \\
35 & 0.9106 & 0.631 & 1.247 \\
45 & 0.9434 & 0.272 & 1.349 \\
\hline
\end{tabular}

K: relative adsorption capacity; n:adsorption intensity.

According to the Tables 2 and 3, Langmuir adsorption isotherm gave a better fit than the Freundlich model.

\subsubsection{Adsorption Results}

The relationship between dosages of montmorillonite and the percentage removal of SDZ is shown in Fig. 5a. Increasing in the montmorillonite dose from 100 to $600 \mathrm{mg} \mathrm{L}^{-1}$ 
can raise the percentage removal of SDZ from $11.0 \%$ to $16.30 \%$. Fig. 5a also shows negative Zeta potential in the test solution; the higher dose of montmorillonite, the more negative values of Zeta potentials, suggesting that the surface of montmorillonite is negatively charged for the study conditions. Consequently, the negatively charged surface of montmorillonite will affect SDZ adsorption efficiency for various solution pHs and this will be discussed in later session.

The experimental results shown in Fig. 5b demonstrated that sorption time is a crucial factor on the SDZ removal efficiency. The adsorption process of SDZ on montmorillonite can be divided into three phases; the fast adsorption stage (1-10 $\mathrm{min})$, the desorption process (10-60 $\mathrm{min}$ ) and a relative slow sorption phase until reaching to the equilibrium (up to $4 \mathrm{~h}$ ). In the fast stage, the dispersion of SDZ in water and then onto the active sites of montmorillonite was rapidly, which resulted in that SDZ was saturated on the outer surface of montmorillonite and then causing the desorption in a short period (second phase). After that stage, SDZ was diffused and attached into internal pores of montmorillonite, which increasing the mass transfer resistance with time thus reduced sorption speed and leading to the slow absorption stage. Same phenomenon was observed by [52].

Fig. 5c shows the relationship between temperature and initial concentrations of SDZ with adsorbing capacity on montmorillonite. For $24 \mathrm{~h}$ duration of adsorption, the adsorbing capacity increased with increasing in the initial concentration of SDZ, and the adsorbing capacity reached equilibrium while the initial concentration of SDZ was $300 \mathrm{mg}$ $\mathrm{L}^{-1}$. On the other hand, the adsorbing efficient was affected by the reaction temperature; the sorption efficient order was $35^{\circ} \mathrm{C}>25^{\circ} \mathrm{C}>45{ }^{\circ} \mathrm{C}$, suggesting that relative high temperature $\left(45^{\circ} \mathrm{C}\right)$ and low temperature $\left(25^{\circ} \mathrm{C}\right)$ were not conducive to the adsorption of SDZ by montmorillonite.

Variations of SDZ removal efficiency and Zeta potential in respect of $\mathrm{pH}$ values were shown in Fig. 5d. It can be observed that for a given montmorillonite dose (100 mg L $\left.\mathrm{L}^{-1}\right)$ and reaction duration of $24 \mathrm{~h}$, the removal of SDZ increased first and then decreased with increasing in solution $\mathrm{pH}$, and the favorable sorption for SDZ was at $\mathrm{pH}$ 6. This could be elucidated that for $\mathrm{pH}<6$ the adsorption of SDZ on montmorillonite surfaces was dominated by the mechanism of cation exchange [53].

On the other hand, the Zeta potential of montmorillonite-SDZ mixture was negative (Fig. 5d), suggesting the surface of montmorillonite was negatively charged for the $\mathrm{pH}$ range of the experiments. Thus, the adsorption amount was determined by the ionic forms of SDZ. When the $\mathrm{pH}$ of the mixed solution was higher than 6.5, SDZ was mainly dominated as the form of anions, which is mutually exclusive with the negative surface 
charge of montmorillonite; and thus adsorption amount of SDZ dropped sharply. This also can be demonstrated in terms of the dissociated SDZ species based on its dissociation constants, $\mathrm{pKa}_{1}$ of 1.57 and $\mathrm{pKa}_{2}$ of 6.50 , respectively. Various dissociated species could be $\mathrm{SDZ}^{+}, \mathrm{SDZ}^{0}$ and $\mathrm{SDZ}^{-}$at different $\mathrm{pH}$ conditions [49], when $\mathrm{pH}$ was $>6.5$, the dominant species will be anionic based SDZ ${ }^{-}$and therefore, the sorption of SDZ decreased, and it dropped down sharply when was $\mathrm{pH}>9$. It is obvious that the $\mathrm{pH}$ can affect the surface state of adsorbent, interface potential, and solutes' dissociation status and then the sorption performance in general [54-55].

Fig. 5. SDZ adsorption by montmorillonite. a) Effect of montmorillonite dosages on the SDZ removal and variations of Zeta potential $\left([\mathrm{SDZ}]=5.0 \mathrm{mg} \mathrm{L}^{-1}\right.$ or $0.02 \mathrm{mM}$; $\mathrm{pH}=$ $7.0 \pm 0.1 ; \mathrm{T}=25.0^{\circ} \mathrm{C}$; reaction time $=24 \mathrm{~h}$ ); b) Effect of adsorption time on the SDZ removal by montmorillonite ([montmorillonite $]=1000 \mathrm{mg} \mathrm{L}^{-1}$; [SDZ] $=5.0 \mathrm{mg} \mathrm{L}^{-1}$ or 0.02 $\left.\left.\mathrm{mM} ; \mathrm{pH}=7.0 \pm 0.1 ; \mathrm{T}=25.0^{\circ} \mathrm{C}\right) ; \mathrm{c}\right)$ Effect of temperature on SDZ removal by montmorillonite ([montmorillonite] $=1000 \mathrm{mg} \mathrm{L}^{-1} ; \mathrm{pH}=7.0 \pm 0.1$; sorption time $=24 \mathrm{~h}$ ); $\mathrm{d}$ ) Effect of $\mathrm{pH}$ on SDZ removal and Zeta potential ([montmorillonite] $=100 \mathrm{mg} \mathrm{L}^{-1}$, [SDZ] $=5.0 \mathrm{mg} \mathrm{L}^{-1}$ or $0.02 \mathrm{mM}$; $\mathrm{T}=25.0^{\circ} \mathrm{C}$; reaction time $=24 \mathrm{~h}$ )

\subsection{Synergistic effects of combined degradation and adsorption on the removal of SDZ}

Multiple trials were conducted to validate a hypothesis of a positive synergetic effect of combined degradation and adsorption on the removal of SDZ. The studies were arranged at three dosing sequences; ferrate(VI) oxidation first $(1 \mathrm{~h})$ followed by montmorillonite adsorption $(24 \mathrm{~h})$, the adsorption first $(24 \mathrm{~h})$ and the oxidation $(1 \mathrm{~h})$ afterwards and a simultaneous process $(25 \mathrm{~h})$ with oxidation and adsorption. The early results showed that the optimal ferrate(VI) oxidation was achieved at $\mathrm{pH} 7$ which gave greater SDZ removal and the optimal adsorption was obtained at $\mathrm{pH} 6$, but its performance was slightly better than that achieved at $\mathrm{pH}$ 7. Thus, the combined oxidation/adsorption processes were using pH 7 but not 6 . Fig. 6 shows that for the given test conditions, all three combined processes (Fig. 6, Left), no matter what dosing sequences, can promote the removal of SDZ; $76.20 \%$ by the simultaneous oxidation/adsorption, $73.70 \%$ by the oxidation first and $72.10 \%$ by the adsorption first. It is obvious that the combined processes were superior to the process of either the oxidation alone (60\%) or adsorption alone (10\%) (Fig. 6, Right) to remove the SDZ, and the synergetic effect of combined oxidation/adsorption was confirmed. The plausible explanation of this includes two points: on one hand, that 
combined ferrate(VI) oxidation with montmorillonite adsorption had additive effects; during the oxidation of SDZ, ferrate(VI) was reduced to ferric-oxide like products [56] which played the role as coagulant/precipitant, and montmorillonite acted as both adsorbent and coagulant aids to promote the flocculation/sedimentation [57] and sorption and thus reduced the turbidity of the solution, leading more SDZ could be removed from the test solution; On the other hand, there was a neutralization between the high positive charge intermediate formed by the decomposition of Ferrate(VI) and the negatively charged montmorillonite, reduce the repulsion between particles, and tend to agglomerate to form larger flocs. The sedimentation performance of the flocs was improved, so that the SDZ which could not be removed by the oxidation and adsorption was co-precipitated with the flocs formed and removed.

Fig. 6. Synergistic effects of combined ferrate(VI) oxidation/montmorillonite adsorption on the removal of SDZ ([Fe(VI)]:[SDZ] $=10: 1$, [montmorillonite $]=100 \mathrm{mg} \mathrm{L}^{-1}$, [SDZ] $=$ $5.0 \mathrm{mg} \mathrm{L}^{-1}$ or $0.02 \mathrm{mM}$; $\mathrm{pH}=7.0 \pm 0.1 ; \mathrm{T}=25.0{ }^{\circ} \mathrm{C}$; reaction time $=25 \mathrm{~h}$ ).

Left: three combined processes; Right: oxidation alone or adsorption alone process

\subsection{SDZ degradation pathways and oxidation products'formation}

SDZ compound contains a pyrimidine group and a benzene ring. In the oxidation process SDZ will be degraded to form various oxidation products including some of completion oxidation products, $\mathrm{CO}_{2}$. The completion oxidation of an organic compound can be estimated by the measurement of residual total organic carbon (TOC) concentration of the treated solution, which can also be referred to the mineralization efficiency. Fig. 7 shows the removal of TOC vs that of SDZ. Notably, for 10 min reaction, the removal of SDZ can reach $60.0 \%$; in contrast, the removal of TOC was $17.0 \%$. With the increase of reaction time, the removal of SDZ and TOC was not further improved, indicating that the oxidation of SDZ by ferrate(VI) was not complete, or, the mineralization efficiency of SDZ by ferrate(VI) oxidation was only $17.0 \%$ and this may be owning to the stable structure of pyrimidine and benzene ring in SDZ.

Relatively low TOC reduction as shown in Fig. 7 suggests that ferrate (VI) did not completely degrade SDZ but only oxidized SDZ into macromolecular like oxidation byproducts (shown in later sections). This may be lead to the toxicity or, antibiotic activates remained in the treated solutions. One of previous studies showed that there would be no toxicity when sulfonamides (including SDZ) were partially oxidized even DOC reduction 
was not completely [58]. Another research found some different results; that the toxicity of photocatalytic degradation by-products of sulfonamides (including SDZ) was observed but it was significantly lower than toxicity of the original sulfonamides' solutions [59]. Apparently, the toxicity or antibiotic activates of SDZ's oxidation by-products will rely on the properties of the given SDZ solutions studied, the oxidation process and operating conditions used to degrade SDZ, and also would be dependent on the type of microorganisms used in performing the toxicity study. And then, the toxicity of oxidation byproducts from reactions between SDZ and ferrate(VI) remains an important subject to be studied and this is to be one of future work in this research area.

Fig. 7. Removal of TOC and SDZ ([Fe(VI)]:[SDZ] = 10:1; $[\mathrm{SDZ}]=0.02 \mathrm{mM} ; \mathrm{pH}=7.0 ; \mathrm{T}$ $\left.=25.0^{\circ} \mathrm{C}\right)$

Fig. 8 analyzes oxidation products of SDZ by ferrate(VI), which was mainly a substance with a $\mathrm{m} / \mathrm{z}$ ratio of 280.25 . It has been acknowledged [36] that when ferrate(VI) oxidizes organics, ferrate(VI) does not directly form Fe(III) in a one-step reaction, but gradually forms $\mathrm{Fe}(\mathrm{V}), \mathrm{Fe}(\mathrm{IV})$ and $\mathrm{Fe}(\mathrm{III})$ by single electron transfer [60-61] and this is also the case for the SDZ degradation by ferrate(VI). The charge carried by $-\mathrm{NH}_{2}$ on SDZ was gradually transferred by $\mathrm{Fe}(\mathrm{VI})$ in a single electron to form -NO and $\mathrm{Fe}(\mathrm{III})$. The -NO was unstable and finally oxidized to form $-\mathrm{NO}_{2}$. The reaction process was analogous to the previous study of aniline by ferrate(VI) [62]. In combination with previous studies [63], for sulfonamides containing anilino groups, $\mathrm{Fe}(\mathrm{VI})$ mainly oxidizes $-\mathrm{NH}_{2}$ (see Fig. 9), and failed to achieve complete mineralization. Although ferrate (VI) has strong oxidizing properties and can quickly remove SDZ, this study found that ferrate(VI) cannot open SDZ's benzene rings but only oxidized $-\mathrm{NH}_{2}$ on $\mathrm{SDZ}$ structure to $-\mathrm{NO}_{2}$ group and produced the final oxidation product (shown in Fig. 9). This is identical to that in a recent published work [48].

This study comprehensively investigated SDZ removal by either ferrate(VI) degradation or montmorillonite adsorption and the stated results disclosed that neither of these two processes could efficiently remove SDZ. An innovative combined ferrate(VI) oxidation with montmorillonite adsorption indeed has shown benefits to the overall SDZ removal performance. The technology developed through this study is promising, which can be applied in the treatment of sulfadiazine in water and waste waters. However, it is necessarily to bear in mind that limited mineralization of sulfadiazine happened when it was oxidized by ferrate(VI); the oxidation products containing $-\mathrm{NO}_{2}$ groups might possess 
toxicity [64] and montmorillonite adsorption might not remove these by-products thoroughly. And then, further investigations should be carried out to assess the toxicity of the treated effluents and to promote much high efficiency to remove SDZ.

Fig. 8. GC-MS mass spectrum of SDZ oxidized by ferrate(VI)

Fig. 9. Possible pathway of SDZ degradation by ferrate(VI)

\section{Conclusions}

Results of the treatment of SDZ by ferrate(VI) oxidation and montmorillonite adsorption in aqueous solution showed that when the molar ratio was 10:1 (Fe(VI):SDZ, molar ratio) and reaction time of $15 \mathrm{~min}$, the removal efficiency of SDZ by ferrate(VI) alone can reach $60.40 \%$. And with the increasing in dosage of ferrate(VI) up to $50: 1$ (Fe(VI):SDZ), the removal efficiency of SDZ reached to $99.9 \%$ degradation for $60 \mathrm{~min}$. Moreover, $\mathrm{pH}<7$ can effectively improve the degradation rate of SDZ. Additionally, the degradation of SDZ by ferrate(VI) fitted in pseudo-order equation and the kinetic rate constant was derived as $2.97 * 10^{-4} \mathrm{~L}^{2} \cdot \mathrm{mg}^{-2} \cdot \mathrm{min}^{-1}$. On the other hand, the adsorption of SDZ by montmorillonite alone showed that increasing in the montmorillonite dose from 100 to $600 \mathrm{mg} \mathrm{L}^{-1}$ can raise the percentage removal of SDZ from $11.0 \%$ to $16.30 \%$, the sorption equilibrium was reached at $4 \mathrm{~h}$, and $\mathrm{pH} 6$ and sorption temperature of $35^{\circ} \mathrm{C}$ were favorable to the optimal performance.

When combined ferrate(VI) oxidation/montmorillonite adsorption was used to remove SDZ, all three combined processes can promote the removal of SDZ but the simultaneous oxidation/adsorption can achieve the outperforming removal of SDZ (76.20\%) in comparison with the oxidation alone $(60 \%)$ or adsorption alone $(10 \%)$ for the same given conditions, and the synergetic effect of combined oxidation/adsorption was demonstrated. However, due to the stable structure of SDZ, ferrate(VI) incompletely oxidized SDZ and most oxidation product formed was that aromatic- $\mathrm{NO}_{2}$ containing groups macromolecules which were oxidized from the initial $\mathrm{SDZ}$ containing $-\mathrm{NH}_{2}$ groups.

\section{Acknowledgements}


Authors wish to express their appreciation for the financial support given by The Chinese National Natural Science Foundation to run this study (Grant No.: 21776262).

\section{References}

[1] Jiang J.-Q., Zhou, Z., Sharma, V.K., 2013. Occurrence, transportation, monitoring and treatment of emerging micro-pollutants in waste water - A review from global views, Microchem. J. 110, 292-300.

[2] Roca Jalil, M.E., Baschini, M., Sapag, K., 2015. Influence of pH and antibiotic solubility on the removal of ciprofloxacin from aqueous media using montmorillonite. Appl. Clay Sci. 114, 69-76.

[3] Akinbowale, O.L., Peng, H., Barton, M.D., 2006. Antimicrobial resistance in bacteria isolated from aquaculture sources in Australia. J. Appl. Microbiol. 100, 1103-1113.

[4] Akinbowale, O.L., Peng, H., Barton, M.D., 2007. Diversity of tetracycline resistance genes in bacteria from aquaculture sources in Australia. J. Appl. Microbiol. 103, 2016-2025.

[5] Lindqvist, N., Tuhkanen, T., Kronberg, L., 2005. Occurrence of acidic pharmaceuticals in raw and treated sewages and in receiving waters. Water Res. 39, 2219-2228.

[6] Lishman, L., Smyth, S.A., Sarafin, K., Kleywegt, S., Toito, J., Peart, T., Lee, B., Servos, M., Beland, M., Seto, P., 2006. Occurrence and reductions of pharmaceuticals and personal care products and estrogens by municipal wastewater treatment plants in Ontario, Canada. Sci. Total Environ. 367, 544-558.

[7] Nakada, N., Tanishima, T., Shinohara, H., Kiri, K., Takada, H., 2006. Pharmaceutical chemicals and endocrine disrupters in municipal wastewater in Tokyo and their removal during activated sludge treatment. Water Res. 40, 3297-3303.

[8] Comeau, F., Surette, C., Brun, G.L., Losier, R., 2008. The occurrence of acidic drugs and caffeine in sewage effluents and receiving waters from three coastal watersheds in Atlantic Canada. Sci. Total Environ. 396, 132-146.

[9] Wang, L., Ying, G.G., Zhao, J.L., Yang, X.B., Chen, F., Tao, R., Liu, S., Zhou, L.J., 2010. Occurrence and risk assessment of acidic pharmaceuticals in the Yellow River, Hai River and Liao River of north China. Sci. Total Environ. 408, 3139-3147.

[10] Wang, J., Wang, S., 2016. Removal of pharmaceuticals and personal care products (PPCPs) from wastewater: A review. J Environ. Manage. 182, 620-640.

[11] Biswal, B.K., Mazza, A., Masson, L., Gehr, R., Frigon, D., 2014. Impact of wastewater treatment processes on antimicrobial resistance genes and their cooccurrence with virulence genes in Escherichia coli. Water Res. 50, 245-253.

[12] Sun, Q., Li, M., Ma, C., Chen, X., Xie, X., Yu, C.P., 2016. Seasonal and spatial variations of PPCP occurrence, removal and mass loading in three wastewater treatment plants located in different urbanization areas in Xiamen, China. Environ. Pollut. 208, 371-381.

[13] Batt, A.L., Snow, D.D., Aga, D.S., 2006. Occurrence of sulfonamide antimicrobials 
in private water wells in Washington County, Idaho, USA. Chemosphere 64, 19631971.

[14] Pan, M., Chu, L.M., 2018. Occurrence of antibiotics and antibiotic resistance genes in soils from wastewater irrigation areas in the Pearl River Delta region, southern China. Sci. Total Environ. 624, 145-152.

[15] Zhou, L.J., Ying, G.G., Zhao, J.L., Yang, J.F., Wang, L., Yang, B., Liu, S., 2011. Trends in the occurrence of human and veterinary antibiotics in the sediments of the Yellow River, Hai River and Liao River in northern China. Environ. Pollut. 159, 1877-1885.

[16] Peng, C., Min, F., Liu, L., 2017. Effect of pH on the adsorption of dodecylamine on montmorillonite: Insights from experiments and molecular dynamics simulations. Appl. Surface Sci. 425, 996-1005.

[17] Yang, J.-F., He, M., Wu, T.-F., Hao, A.-P., Zhang, S.-B., Chen, Y.-D., Zhou, S.-B., Zhen, L.-Y., Wang, R., Yuan, Z.-L., Deng, L., 2018. Sulfadiazine oxidation by permanganate: Kinetics, mechanistic investigation and toxicity evaluation. Chem. Eng. J. 349, 56-65.

[18] Yan, C., Yang, Y., Zhou, J., Liu, M., Nie, M., Shi, H., Gu, L., 2013. Antibiotics in the surface water of the Yangtze Estuary: occurrence, distribution and risk assessment. Environ. Poll. 175, 22-29.

[19] Ma, R., Wang, B., Yin, L., Zhang, Y., Deng, S., Huang, J., Wang, Y., Yu, G., 2017. Characterization of pharmaceutically active compounds in Beijing, China: Occurrence pattern, spatiotemporal distribution and its environmental implication. J. Hazard. Mater. 323, 147-155.

[20] Burke, V., Richter, D., Greskowiak, J., Mehrtens, A., Schulz, L., Massmann, G.J.W.E.R., 2016. Occurrence of Antibiotics in Surface and Groundwater of a Drinking Water Catchment Area in Germany. Water Environ. Res. 88, 652-659.

[21] Sakai, N., Mohd Yusof, R., Sapar, M., Yoneda, M., Ali Mohd, M., 2016. Spatial analysis and source profiling of beta-agonists and sulfonamides in Langat River basin, Malaysia. Sci. Total Environ. 548-549, 43-50.

[22] Yu, Z., Yin, D., Deng, H., 2015. The combinational effects between sulfonamides and metals on nematode Caenorhabditis elegans. Ecotoxicol Environ. Saf. 111, 6671.

[23] Varo, I., Navarro, J.C., Rigos, G., Ramo, J.D., Calduch-Giner, J.A., Hernandez, A., Pertusa, J., Torreblanca, A., 2013. Proteomic evaluation of potentiated sulfa treatment on gilthead sea bream (Sparus aurata L.) liver. Aquaculture 376-379, 3644.

[24] Wollenberger., L., Halling-Sùrensen., B., Kusk., K.O., 2000. Acute and chronic toxicity of veterinary antibiotics to Daphnia magna. Chemosphere 40, 723-730.

[25] Li, Z., Chang, Q., Li, S., Gao, M., She, Z., Guo, L., Zhao, Y., Jin, C., Zheng, D., Xu, Q., 2017. Impact of sulfadiazine on performance and microbial community of a sequencing batch biofilm reactor treating synthetic mariculture wastewater. Bioresource Technol. 235, 122-130.

[26] Larcher, S., Yargeau, V., 2012. Biodegradation of sulfamethoxazole: current knowledge and perspectives. Appl. Microbiol. Biotechnol. 96, 309-318. 
[27] Baran, W., Adamek, E., Ziemiańska, J., Sobczaka, A. 2011. Effects of the presence of sulfonamides in the environment and their influence on human health. J. Hazard. Mater. 196(30), 1-15.

[28] Batista, A.P.S., Pires, F.C.C., Teixeira, A.C.S.C., 2014. Photochemical degradation of sulfadiazine, sulfamerazine and sulfamethazine: Relevance of concentration and heterocyclic aromatic groups to degradation kinetics. Journal of Photochemistry and Photobiology A: Chemistry 286, 40-46.

[29] Gomez-Ramos Mdel, M., Mezcua, M., Aguera, A., Fernandez-Alba, A.R., Gonzalo, S., Rodriguez, A., Rosal, R., 2011. Chemical and toxicological evolution of the antibiotic sulfamethoxazole under ozone treatment in water solution. J. Hazard. Mater. 192, 18-25.

[30] Ji, Y., Fan, Y., Liu, K., Kong, D., Lu, J., 2015. Thermo activated persulfate oxidation of antibiotic sulfamethoxazole and structurally related compounds. Water Res. 87, 19.

[31] Kim, C., Panditi, V.R., Gardinali, P.R., Varma, R.S., Kim, H., Sharma, V.K., 2015. Ferrate promoted oxidative cleavage of sulfonamides: Kinetics and product formation under acidic conditions. Chem. Eng. J. 279, 307-316.

[32] Jiang, J.-Q., Lloyd, B. 2002. Progress in the development and use of ferrate (vi) salt as an oxidant and coagulant for water and wastewater treatment. Water Res. 36, 1397-1408.

[33] Chen, J., Wu, N.N., Xu, X.X., Qu, R.J., Li, C.G., Pan, X.X., Wei, Z.B., Wang, Z.Y., 2018. Fe(VI)-Mediated Single-Electron Coupling Processes for the Removal of Chlorophene: A Combined Experimental and Computational Study. Environ. Sci. Technol. 52(21), 12592-12601.

[34] Jiang, J.-Q., Wang, S., Panagoulopoulos, A., 2006. The exploration of potassium ferrate (VI) as a disinfectant/coagulant in water and wastewater treatment. Chemosphere 63(2), 212-219.

[35] Licht, S., 2010. A High Capacity Li-Ion Cathode: The Fe(III/VI) Super-Iron Cathode. Energies 3, 960-972.

[36] Jiang, J.-Q., 2014. Advances in the development and application of ferrate(VI) for water and wastewater treatment. J. Chem. Technol. Biotechnol. 89, 165-177.

[37] Sharma, V.K., Zboril, R., Varma, R.S., 2015. Ferrates: greener oxidants with multimodal action in water treatment technologies. Acc. Chem. Res. 48, 182-191.

[38] Feng, M.B., Jinadatha, C., Mcdonald, T. J., Sharma, V.K., 2018. Accelerated Oxidation of Organic Contaminants by Ferrate(VI): The Overlooked Role of Reducing Additives. Environ. Sci. Technol. 52, 11319-11327.

[39] Feng, M,B., Cizmas, L., Wang, Z.Y., Sharma. V.K., 2017. Activation of ferrate(VI) by ammonia in oxidation of flumequine: Kinetics, transformation products, and antibacterial activity assessment. Chem. Eng. J. 323 (2017) 584-591.

[40] Feng, M,B., Sharma. V.K., 2018. Enhanced oxidation of antibiotics by ferrate(VI)sulfur(IV) system: Elucidating multi-oxidant mechanism. Chem. Eng. J. 341, 137145.

[41] Horsing, M., Ledin, A., Grabic, R., Fick, J., Tysklind, M., Jansen, J.I.C., Andersen, H.R., 2011. Determination of sorption of seventy-five pharmaceuticals in sewage 
sludge. Water Res. 45, 4470-4482.

[42] Wu, Q., Que, Z., Li, Z., Chen, S., Zhang, W., Yin, K., Hong, H., 2018. Photodegradation of ciprofloxacin adsorbed in the intracrystalline space of montmorillonite. J. Hazard. Mater. 359, 414-420.

[43] Jiang, J.-Q., Zeng, Z. 2003. Comparison of modified montmorillonite adsorbents. Part II: The effects of the type of raw clays and modification conditions on the surface properties and adsorption performance of modified clays. Chemosphere 53(1), 53-62.

[44] Rush, J.D., Zhao, Z., Bielski, B.H.J., 1996. Reaction of ferrate(VI)/ferrate(V) with hydrogen peroxide and superoxide anion-A stopped-flow and premix pulse radiolysis study. Free Radical Res. 24, 187-198.

[45] Sharma, V.K., Sohn, M., Anquandah, G.A.K., Nesnas, N., 2012. Kinetics of the oxidation of sucralose and related carbohydrates by ferrate(VI). Chemosphere 87, 644-648.

[46] Sharma, V.K., Mishra,S.K., Nesnas, N., 2006. Oxidation of sulfonamide antimicrobials by ferrate. Environ. Sci. Technol. 40, 7222-7227.

[47] Lee, Y. Zimmermann, S.G., Kieu, A.T., and von Gunten, U. 2009. Ferrate (Fe(VI)) Application for Municipal Wastewater Treatment: A Novel Process for Simultaneous Micropollutant Oxidation and Phosphate Removal. Environ. Sci. Technol. 43, 38313838.

[48] Feng, M. Baum, J. C., Nesnas, N., Lee, Y., Huang, C.-H. and Sharma, V.K., 2019. Oxidation of Sulfonamide Antibiotics of Six-Membered Heterocyclic Moiety by Ferrate(VI): Kinetics and Mechanistic Insight into $\mathrm{SO}_{2}$ Extrusion. Environ. Sci. Technol. 53, 2695-2704.

[49] Langmuir, I., 1918. Adsorption of gases on plane surfaces of glass, mica and platinum. J.Amer. Chem. Soc. 40, 1361-1403.

[50] Fruendlich, H., 1906. Adsorption in solution. Phy. Chem. 57, 384-410.

[51] Aksu, Z., Kabasakal, E., 2004. Batch adsorption of 2,4-dichloropheoxy-acetic acid $(2,4-D)$ from aqueous solution by granular activated carbon. Sep. Purific. Technol. $35,223-240$.

[52] Liu, X., Liu, Y., Lu, S., Guo, W., Xi, B., 2018. Performance and mechanism into $\mathrm{TiO}_{2} /$ Zeolite composites for sulfadiazine adsorption and photodegradation. Chem. Eng. J. 350, 131-147.

[53] Lv, G., Pearce, C.W., Gleason, A., Liao, L., MacWilliams, M.P., Li, Z., 2013. Influence of montmorillonite on antimicrobial activity of tetracycline and ciprofloxacin. Journal of Asian Earth Sci. 77, 281-286.

[54] Bui, T.X., Choi, H., 2009. Adsorptive removal of selected pharmaceuticals by mesoporous silica SBA-15. J. Hazard. Mater. 168, 602-608.

[55] Fukahori, S., Fujiwara, T., Ito, R., Funamizu, N., 2011. pH-Dependent adsorption of sulfa drugs on high silica zeolite: Modeling and kinetic study. Desalination 275, 237 242.

[56] George, A.K., Sharma, V.K,. 2013. Ferrate (VI) oxidation of propranolol: Kinetics and products. Chemosphere 91(1), 105-109.

[57] Wang, H.Y., Liu, Y.B., Jiang, J.-Q., 2016. Reaction kinetics and oxidation product 
formation in the degradation of acetaminophen by ferrate (VI). Chemosphere 155, 583-590.

[58] Gokulakrishnan, S., Parakh, P., Prakash, H. 2012. Degradation of malachite green by potassium persulphate, its enhancement by 1,8-dimethyl-1,3,6,8,10,13hexaazacyclotetradecane nickel(II) perchlorate complex, and removal of antibacterial activity. J. Hazard. Mater. 213-214, 19-27.

[59] Baran, W., Sochacka, J., Wardas, W. 2006. Toxicity and biodegradability of sulfonamides and products of their photocatalytic degradation in aqueous solutions. Chemosphere 65(8), 1295-1299.

[60] Sharma, V.K., 2002. Potassium ferrate(VI): an environmentally friendly oxidant. Advances in Environ. Res. 6(2),143-156.

[61] Sharma, V.K., 2010. Oxidation of inorganic compounds by ferrate(VI) and ferrate(VI): one-electron and two-electron transfer steps. Environ. Sci. Technol. 44(13), 5148-5152.

[62] Huang, H., Sommerfeld, D., Dunn, B.C., 2001. Ferrate(VI) oxidation of aniline. J. Chem. Soc.-Dalton Transactions 8, 1301-1305.

[63] Sharma, V.K., Mishra, S.K., Nesnas, N., 2006. Oxidation of sulfonamide antimicrobials by ferrate(VI)[Fe(VI)O ${ }_{4}{ }^{2-}$. Environ. Sci. Technol. 40(23), 7222-7227.

[64] Zhang, T.Q., Dong, F.L., Luo, F., Li, Cong., 2018. Degradation of sulfonamides and formation of trihalomethanes by chlorination after pre-oxidation with $\mathrm{Fe}(\mathrm{VI})$. J. Environ. Sci. 73, 89-95. 


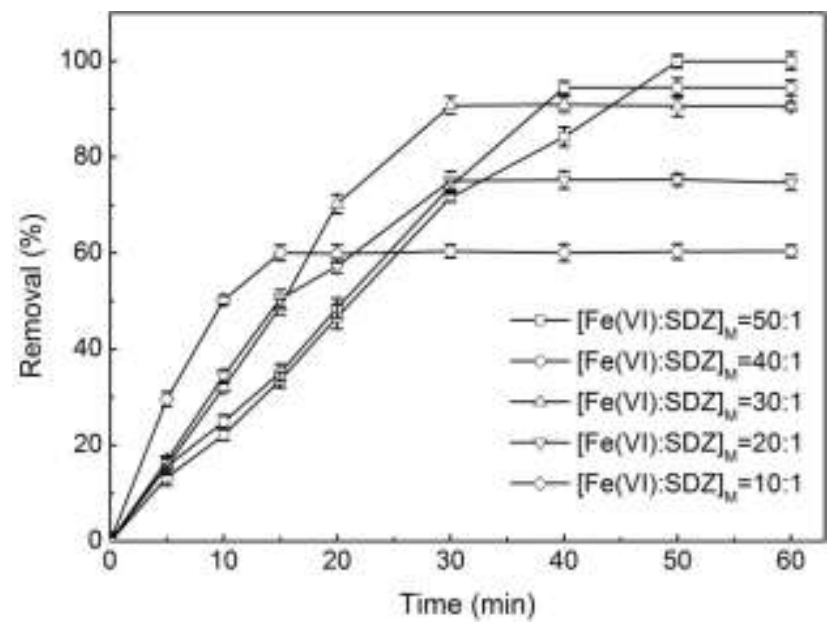

Fig. 1. Effect of ferrate(VI) dose (as molar ratios of Fe(VI):SDZ) and reaction time on the removal of SDZ $\left([\mathrm{SDZ}]_{0}=0.02 \mathrm{mM} ; \mathrm{pH}=7.0 \pm 0.1 ; \mathrm{T}=25.0{ }^{\circ} \mathrm{C}\right)$

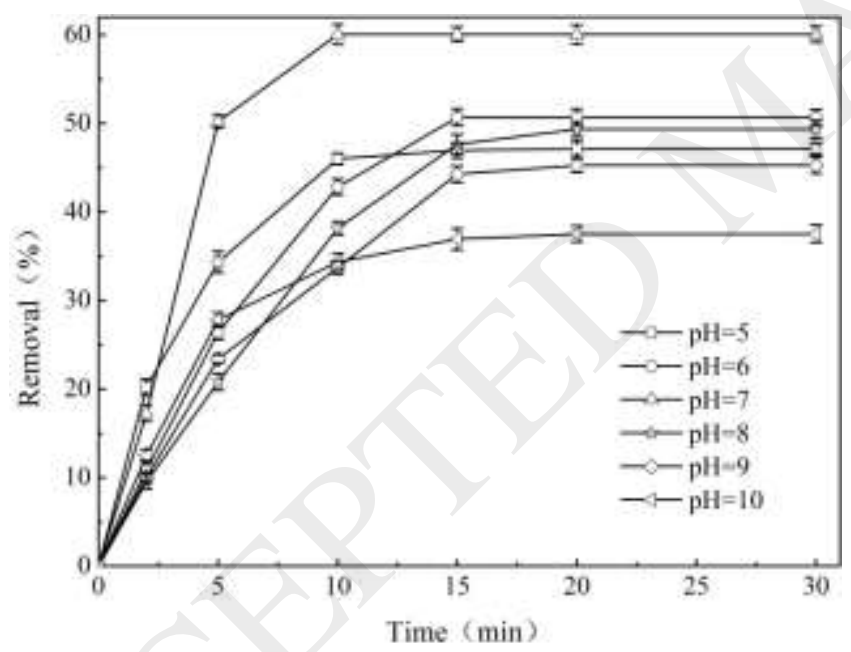

Fig. 2. Effect of different $\mathrm{pH}$ values on SDZ degradation ([Fe(VI)]:[SDZ]=10:1; $[\mathrm{SDZ}]=$ $\left.0.02 \mathrm{mM} ; \mathrm{pH}=5.0-10.0 ; \mathrm{T}=25.0^{\circ} \mathrm{C}\right)$. 


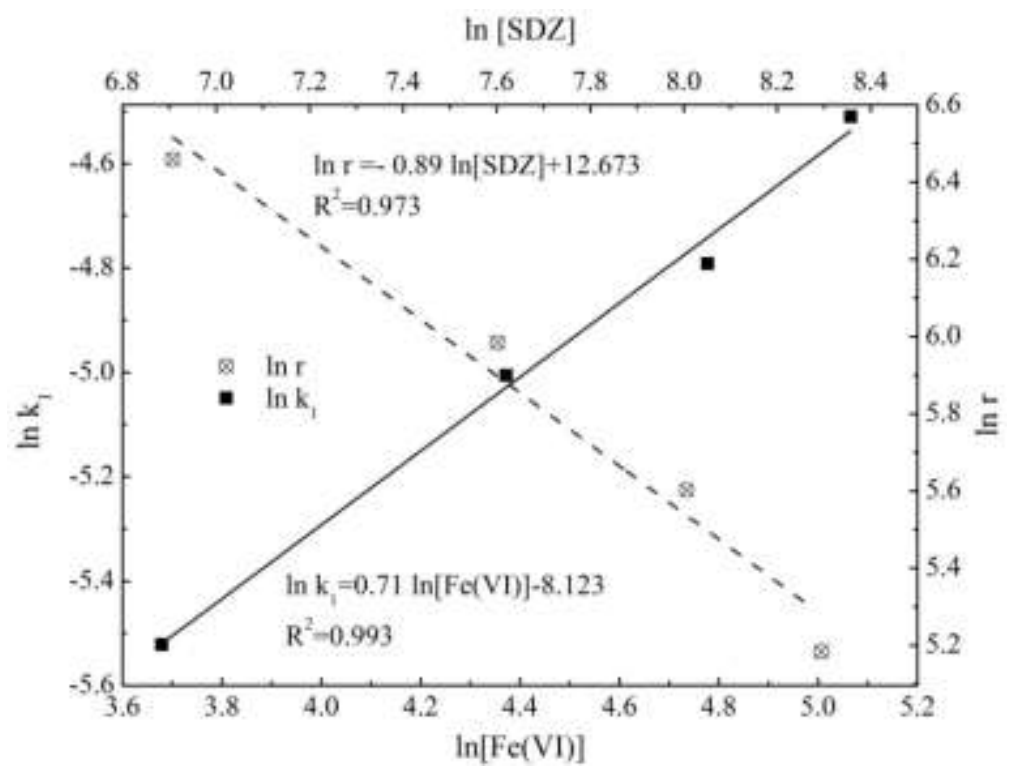

Fig. 3. Kinetics analysis of SDZ degradation by ferrate(VI)

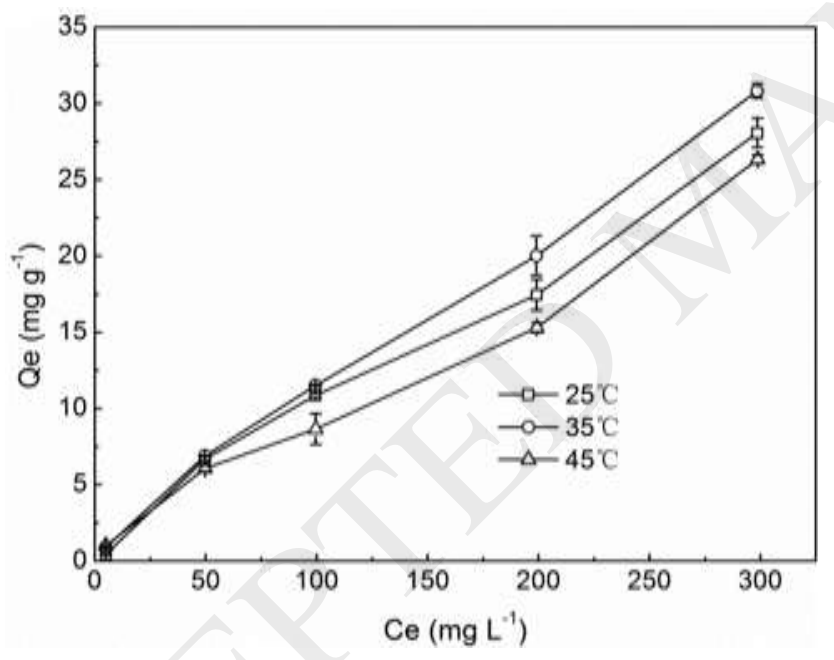

Fig. 4. Adsorption isotherms of SDZ on montmorillonite at different temperatures $\left([\right.$ montmorillonite $]=1000 \mathrm{mg} \mathrm{L}^{-1} ; \mathrm{pH}=7.0 \pm 0.1 ;$ sorption time $\left.=24 \mathrm{~h}\right)$ 

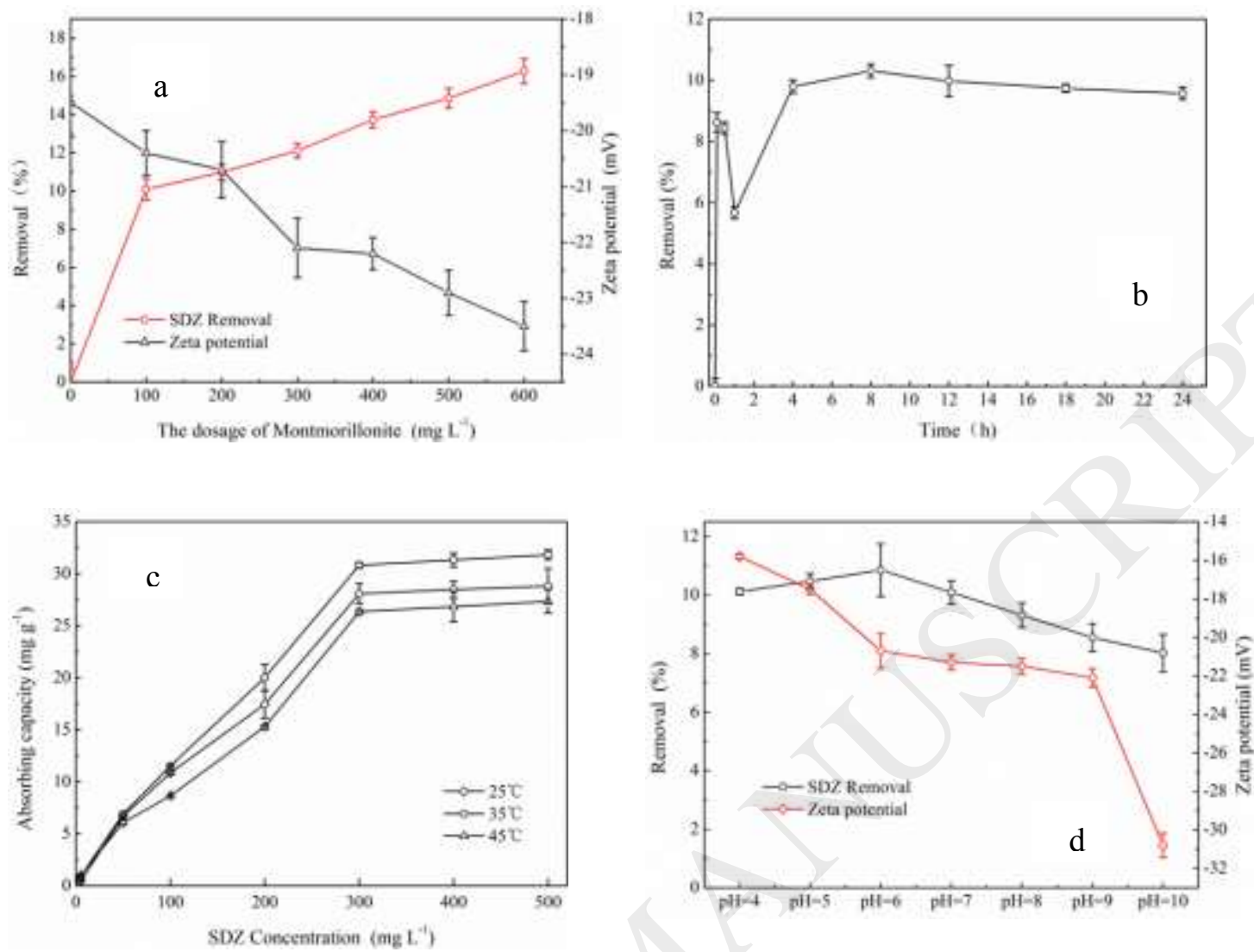

Fig. 5. SDZ adsorption by montmorillonite. a) Effect of montmorillonite dosages on the SDZ removal and variations of Zeta potential $\left([\mathrm{SDZ}]=5.0 \mathrm{mg} \mathrm{L}^{-1}\right.$ or $0.02 \mathrm{mM}$; $\mathrm{pH}=$ $7.0 \pm 0.1 ; \mathrm{T}=25.0^{\circ} \mathrm{C}$; reaction time $=24 \mathrm{~h}$ ); b) Effect of adsorption time on the SDZ removal by montmorillonite ([montmorillonite $]=1000 \mathrm{mg} \mathrm{L}^{-1}$; $[\mathrm{SDZ}]=5.0 \mathrm{mg} \mathrm{L}^{-1}$ or 0.02 $\left.\left.\mathrm{mM} ; \mathrm{pH}=7.0 \pm 0.1 ; \mathrm{T}=25.0^{\circ} \mathrm{C}\right) ; \mathrm{c}\right)$ Effect of temperature on SDZ removal by montmorillonite ([montmorillonite $]=1000 \mathrm{mg} \mathrm{L}^{-1} ; \mathrm{pH}=7.0 \pm 0.1$; sorption time $=24 \mathrm{~h}$ ); ) Effect of $\mathrm{pH}$ on SDZ removal and Zeta potential ([montmorillonite] $=100 \mathrm{mg} \mathrm{L}^{-1}$, [SDZ] $=5.0 \mathrm{mg} \mathrm{L}^{-1}$ or $0.02 \mathrm{mM} ; \mathrm{T}=25.0^{\circ} \mathrm{C}$; reaction time $=24 \mathrm{~h}$ ) 

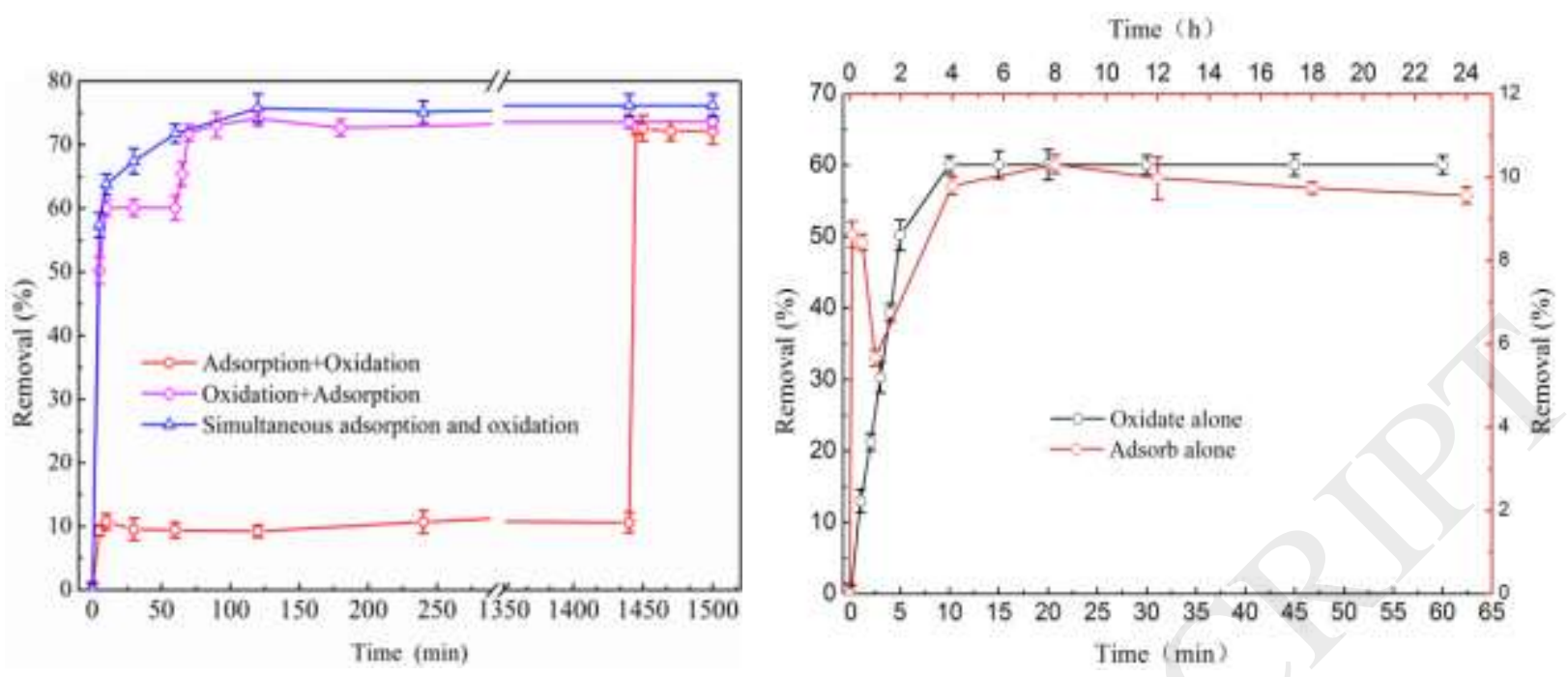

Fig. 6. Synergistic effects of combined ferrate(VI) oxidation/montmorillonite adsorption on the removal of SDZ ([Fe(VI)]:[SDZ] $=10: 1$, [montmorillonite $]=100 \mathrm{mg} \mathrm{L}^{-1}$, [SDZ] $=5.0$ $\mathrm{mgL}^{-1}$ or $0.02 \mathrm{mM} ; \mathrm{pH}=7.0 \pm 0.1 ; \mathrm{T}=25.0^{\circ} \mathrm{C}$; reaction time $\left.=25 \mathrm{~h}\right)$.

Left: three combined processes; Right: oxidation alone or adsorption alone process

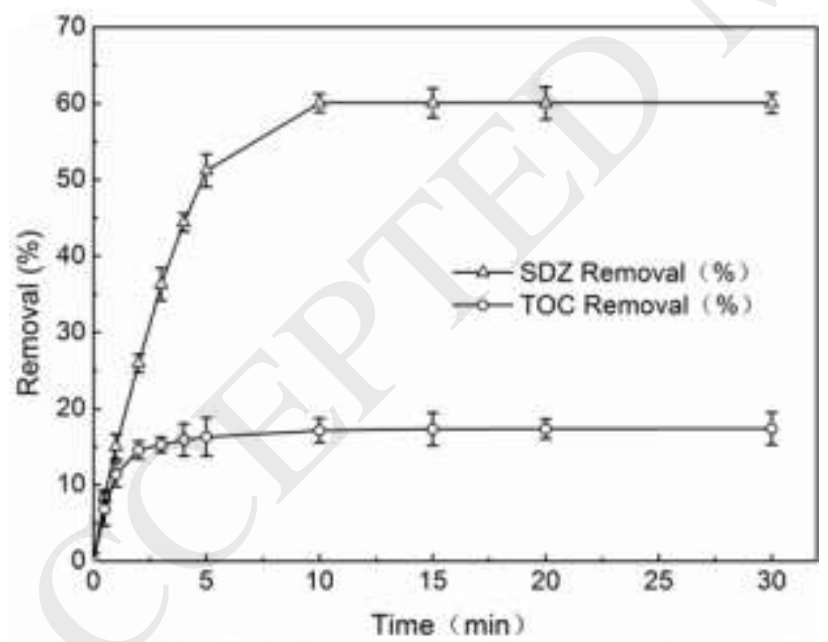

Fig. 7. Removal of TOC and SDZ ([Fe(VI)]:[SDZ $]=10: 1 ;[\mathrm{SDZ}]=0.02 \mathrm{mM} ; \mathrm{pH}=7.0 ; \mathrm{T}$ $\left.=25.0^{\circ} \mathrm{C}\right)$ 


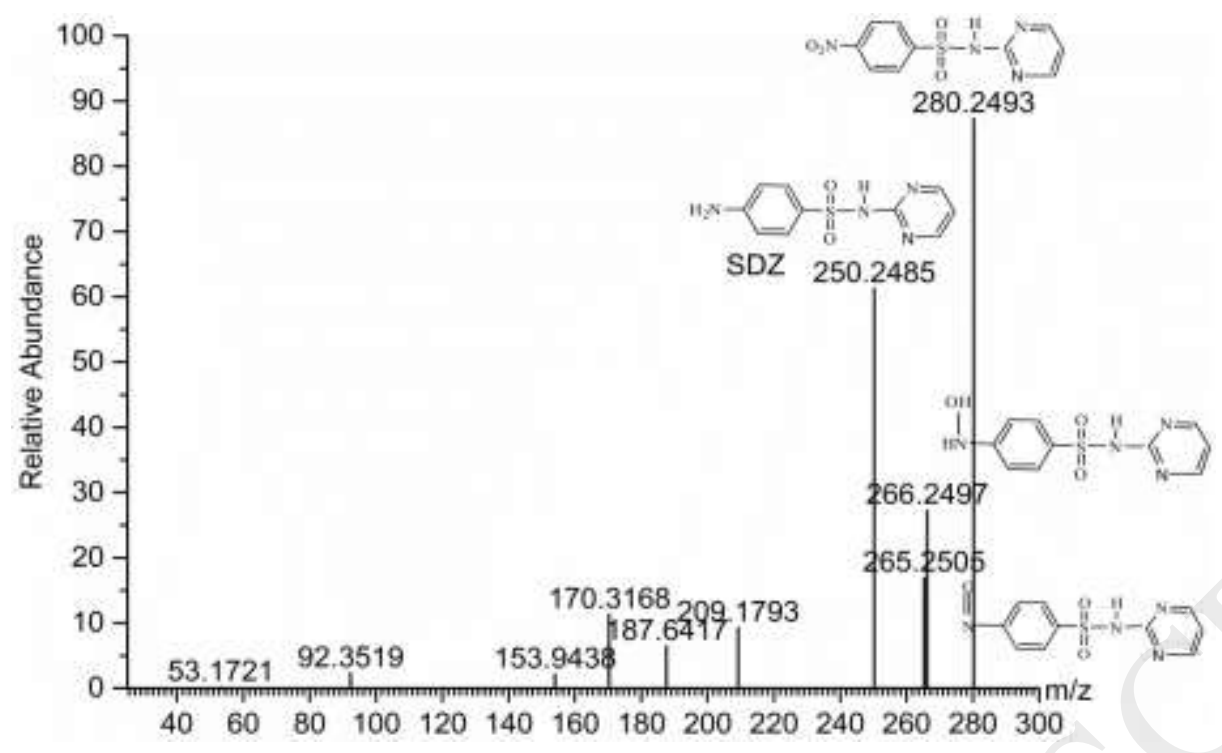

Fig. 8. GC-MS mass spectrum of SDZ oxidized by ferrate(VI)

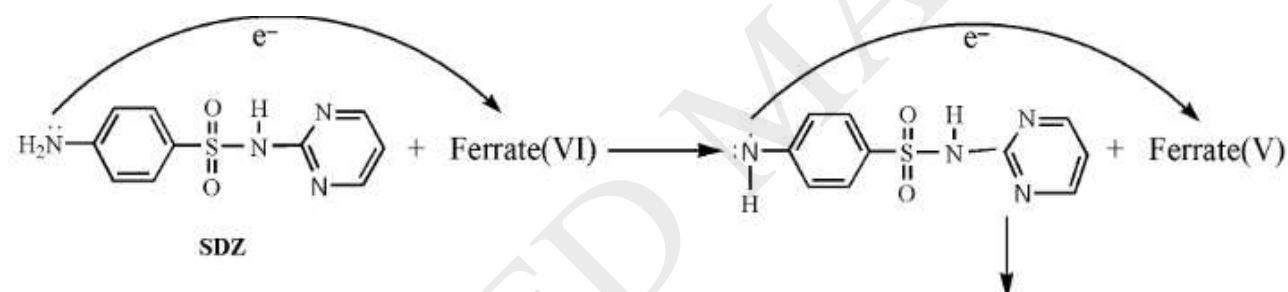<smiles></smiles>

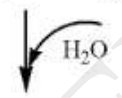

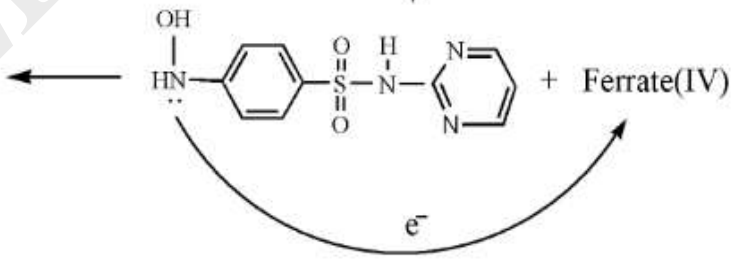

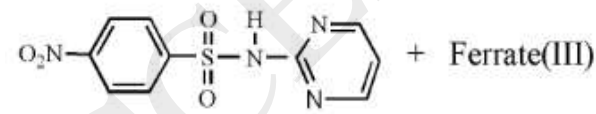

Final OP

Fig. 9. Possible pathway of SDZ degradation by ferrate(VI) 